\title{
ON THE SPECIFIC IDENTITY OF THE AUSTRALIAN PERIPATUS USUALLY SUPPOSED TO BE $P$. LEUCKARTI, SAENGER.
}

\section{By J. J. Fletcher.}

In his well known Monograph (p. 153) Mr. Sedgwick remarks that Peripatus "was reported from Australia in 1869 by Saenger." It is generally supposed also that this was the first intimation of an Australian Peripatus. As a matter of fact there is an earlier notice which has been lost sight of, Professor Leuckart having reported it in 1862 .

The second species of the genus to be made known was $P$. brevis with 14 pairs of claw-bearing legs. One specimen was obtained on Table Mountain in 1829, from which De Blainville described the species in 1837. During the stay of the "Novara" at the Cape, Frauenfeld discovered a second South African species of which he subsequently gave a short account in a paper entitled "Aufenthalt am Cap d. g. Hoffnung während der Weltfahrt der k. k. österreichischen Fregatte Novara."* This paper also has been overlooked, nor is it mentioned in the bibliographical lists of either Sclater (P.Z.S., 1887, p. 133) or Sedgwick (Monograph, p. 209). It was to his record of this paper that Prof. Leuckart appended his introductory notice of the Australian Peripatus.

Frauenfeld says: "Der interessanteste Fund war ein Peripatus unter Steinen . . . Wenn nicht in der neuesten Zeit irgendwo beschrieben, ist derselbe jedenfalls neu, da er in der Fusszahl, 17 Paare, mit keiner der wenigen älterbekannten Arten übereinstimmt." Leuckart's short abstract runs as follows: "Frauenfeld beobachtete am Cap der guten Hoffnung eine neue Art des sonderbaren Gen. Peripatus mit 17 Paar Beinen. A. a. O. S. 88. (Ref.

*Verh. der k.k. zoolog.-botan. Gesellsch. in Wien, Jahrg. 1860, pp. 77-92. 
kann den bis jetzt bekannten Arten dieses Geschlechts gleichfalls eine neue Form aus Australien mit 16 Beinpaaren hinzufügen).*

It is to be noted that in mentioning the Cape species as "mit 17 Paar Beinen," $†$ Leuckart was simply quoting Frauenfeld, who had seen the animal alive, had witnessed the copious discharge of tenacious slime, "aus dem abgestutzten Ende der beiden kurzen unten den Stirnfühlern liegenden Mundfühlern," and who, therefore, excluded the oral papillæ- as Moseley afterwards called them -when counting the legs. But in regard to the Australian Peripatus, it seems evident that Prof. Leuckart intentionally included the oral papillæ among the 16 pairs, but without indicating the fact. For; some years later in noticing Hutton's paper he remarks of $P$. novce-zealandice that like $P$. leuckarti, Säng., it possesses "15 Beinpaare." Now Hutton had expressly said " fifteen pairs of ambulatory legs, and a pair of oral papillæ." Allowing for this, however, there would still seem to have been some misapprehension on Prof. Leuckart's part as to the exact number of claw-bearing legs possessed by his specimen--as the sequel will show.

Subsequently Prof. Leuckart entrusted his specimen of the Australian Peripatus to H. Sänger, who embodied a description of it in a paper dealing in some detail with the anatomy of $P$. capensis, contributed to the "Moskauer Naturforscherversammlung" in 1869. Unfortunately Sänger chose the Russian language as his medium of publication, and in consequence his paper for some twenty-five years has been practically buried. Indeed but for two brief references to it by Prof. Leuckart in the Archiv f. Naturgeschichte, its existence even, as well as its contents, might very well have remained unknown to this day. The bulky

* Archiv f. Naturgescb. Jahrg. xxvii., 1862, ii Bd., p. 235.

†Frauenfeld's specimens were afterwards dealt with by Grube, who described them as P. capensis ("Reise der Novara"). He says there were three specimens, two with 17 pairs of claw-bearing legs, the third with is pairs. He did not attach specific importance to the difference in the number of legs, whence the "pedes uncinigeri utrinque 17 vel 18 verrucosi" of his description. 
quarto volume containing the paper bears the date 1870 on the title page, but 1871 on the paper cover. Leuckart's first mention of it was founded on a preliminary notice or abstract in the "Protocollen der Mosk. Naturforscherversamml." He says : "Verf. untersuchte zwei Arten, den P. capensis, Gr., und eine neue schon vor mehreren Jahren vom Ref. in diesen Berichten erwähnte neuholländische Art, die vom Verf. als P. Leuckarti bezeichnet wird."* Acting on the hint given in this passage I looked through the earlier volumes of the Archiv seriatim until I found the introductory notice, to which reference has been made.

On the publication of the paper itself Leuckart added his oftquoted second notice, $\uparrow$ giving the brief résumé of the characters of the species which has hitherto had to serve as the only available guide to the contents thereof. Leuckart says: "Die neue Art, die aus Neu-Holland stammt, wird folgendermaassen beschrieben: Fünfzehn Paar Fussstumel, von denen das letzte Paar die Geschlechtsöffnung zwischen sich nimmt. Auf der Unterseite der Füsse drei Erhebungen, von denen die eine lang und bogenförmig ist, während die zwei andern kurz und gerade sind. Länge $21 \mathrm{~mm}$. , grösste Breite $3.05 \mathrm{~mm} . "$

This, it will be seen presently, is substantially a translation of the short summary which Sänger added at the end of his des. cription, and from the description itself it is evident that the 15 pairs were intended to include the oral papillæ, though beyond the exceptional use of the suggestive term "Fussstumel" instead of Leuckart's more usual expressions "Beinpaaren" or "Paar Beinen," no intimation of this is given in the summary or the translation. When the context is not left out of account the summary is quite satisfactory; wholly detached there from it is not free from ambiguity. When Peripatus was rediscovered in Australia, and all the specimens forthcoming for some time were found to possess 15 pairs of walking legs, a wrong interpretation was put on the expression "15 Paar Fussstumel " of Leuckart's

*Arch. f. N. xxxv. Jahrg. ii. Bd. 1869, p. 277.

† l.c. xxxvii., ii. Bd., 1871, p. 407. 
abstract. Forthwith naturalists took Sänger's name, unwittingly but unwarrantably fitted it out with new characters, and all the time thought they were strictly following the leader, or only legitimately supplementing his work. Fortunately nothing very much worse has resulted than some considerable confusion of nomenclature, which has not however passed beyond the bounds of rectification,

Sänger's paper has seemed in danger of permanent consignment to oblivion; all the more so, perhaps, under the delusion that of late years observers had supplemented what little was known of it with all that was necessary for the exact identification of the species. It happily occurred to Prof. Spencer when on a visit to England recently, that the satisfaction of knowing exactly what Sänger had said on the subject might possibly prove to be sufficient compensation for the expenditure of the trouble necessary to get at it. He therefore took the matter earnestly in hand, and with the co-operation of Prof. Howes, Mr. H. M. Bernard, and a friend of the latter's, he at length became possessed of a translation of that part of Sänger's paper descriptive of the Australian Peripatus. I have to thank Prof. Spencer not only for a copy of the translation, but also for his permission to make use of it. Before considering the translation, one or two other matters may be noticed.

Some years before the re-discovery of Peripatus in Australia, the New Zealand species came to light. During the stay of H.M.S. "Challenger" at Wellington in July, 1874, Mr. Travers brought specimens to Mr. Moseley, who says that he was unable to refer to special publications at the time, and he thought that it was. "already certainly named;" afterwards on his return to England press of work prevented his giving further attention to the matter. Very shortly after it came under Grube's notice, who refers to it in a paper read in 1875 . I am unable to consult this paper* which is thus noticed by Leuckart: "Grube

* Ber. der schles, Gesellsch. f. Cultur u.s.w. aus den Jahre 1875. Naturwiss. Ber. S. 52. 
berichtet über zwei Peripatusarten, von denen die eine, aus NeuSeeland, mit $P$. Leuckarti, Säng., stimmt, die andere aber unter der Bezeichnung P. peruanus neu beschrieben wird."* Captain Hutton says that he sent specimens to Dublin, without any result. Finally in 1876, Hutton himself described the species as P. novazealandice. Now at this time Hutton evidently was unaware of any record of an Australian Peripatus; nor, under the circumstances, is that at all surprising, seeing that he was at least as badly off for literature as Moseley during the "Challenger's" visit to Wellington. Of Hutton's paper Leuckart remarks :- "Hutton's Abhandlung 'On Peripatus novce-zealandee' (Ann. Mag. Nat. Hist. (4) xviii., Nov., 1876, pp. 361-369, Pl. xvii.) macht uns mit einer Form bekannt, die 15 Beinpaare besitzt, wie der von Sänger (J.-B. 1870, S. 410) beshriebene P. Leuckarti, der unserm Verf. freilich unbekannt geblieben ist, obwohl seine neue Art vielleicht damit zusammenfällt. Jedenfalls ist nicht der $P$. novae-zealandice, sondern der P. Leuckarti die erste Art des Gen. Peripatus, die aus Australien kommt." $\dagger$

When it is borne in mind that at this time only a single specimen of the Australian Peripatus was known, and that a female whose jaw blades were not examined, Sänger not being at liberty to dissect the unique example at his disposal; also that, even in the light of up-to-date knowledge the most striking differences between the allied Australian and New Zealand species- $P$. insignis, Dendy, being left out of consideration for the presentare furnished by the outer jaw blades, and the secondary sexual characters of the males, it would be interesting to know more definitely what it was that suggested the agreement between or possible identity of the two species. Perhaps Grube's paper would settle this point. Was it that too little was known for accurate

* Arch. f. Naturgesch. Jahrg. xliii., 1887, ii. Bd. p. 510.

† L.c. p. 509.

¥ The sex of the type specimen is not mentioned in the description; but in sänger's fig. 31 the genital aperture is lettered $v l$, just as in his fig. of an undoubted female of $P$. capensis. 
comparison; or was it that the authors mentioned thought that in each case the number of claw-bearing legs was the same; or that they knew that the numbers were not identical but regarded the difference as not of specific importance? Moseley's remark penned in 1879, "In the Australian and New Zealand species the number of feet seems fixed"-would, under the circumstances mentioned, seem without force if the last condition held.

On the re-discovery of the Australian Peripatus, first in Queensland (in 1886) - not improbably first in Tasmania, though no record of it was made at the time - then in Victoria (in 1888), and in the same year in New South Wales, and all the specimens met with for several years were found to have 15 pairs of walking legs, it was imagined that these were correctly identified as $P$. leuckarti in supposed agreement with the "funfzehn Paar Fussstumel " of Leuckart's abstract of Sänger's paper. In 1890 Dr. Dendy met with a Victorian Peripatus, with 14 pairs of walking legs, and without an accessory tooth at the base of the fang of the outer jaw blades; and this he quite justifiably considered to be sufficiently distinct to be regarded as a second Australian species, which he accordingly described as $P$. insignis. In 1892 Prof. Spencer obtained similar examples in Tasmania.

We may now turn to

\section{"Sänger's original Diagrosis of Peripatus Leuckartii."}

"Found in New Holland, north-west from Sydney. Fifteen pairs of legs, one pair without claws, fourteen with. This character also found in P. brevis, described by Blanchard. $21 \mathrm{~mm}$. long. Sexual opening between the last pair of appendages, herein differing from $P$. Edwardsii and P. capensis. Colour very nearly black dorsally, greyish ventrally. Papillæ distributed dorsally and ventrally: those on the ventral surface, however, are longer andstand outwards laterally. Between each pair of appendages is a light oval spot without papillæ; this spot corresponds with the dark pits in $P$. capensis, under which occur the glands already described. The papillæ, as in $P$. capensis, are either small and black or large and red, but there are more black than red. Along 
the back runs a longitudinal median line, which consists only of black papillæ, but this line is comparatively faint. The papillæ along the back are arranged in fairly accurate transverse rows, and each row is separated from the next by a furrow. The skin between the papillæ is dark grey. The papillæ on the legs are fairly wide apart. The legs have "soles," which, as in P. capensis, consist of three segments, but the shape of these segments is very different from those of $P$. capensis. The first proximally is black and strongly curved and considerably narrower than the following. The second and third segments are reddish yellow and much shorter but broader than the first. The claw-bearing joint which follows these segments, is distinguished by its four-cornered appearance, due to a pair of papillæ at its outer corners, one on each side ( $P$. capensis has three papillæ). The claws are smaller than those of $P$. capensis. The structure of the mouth is the same as that in other genera [? species] only the soft parts surrounding the mouth and sexual organs are white and not yellowish, but this may be due to the action of alcohol. In addition to this description of the outer appearance of the animal, I give the more important dimensions of the described specimen. Body length $21 \mathrm{~mm}$; greatest breadth $3.03 \mathrm{~mm}$; length of antennæ from 1.6 to 1.73 ; width of antennæ at base 0.389 ; in the middle of antennæ $0 \cdot 26$; length of the oral aperture, including the soft parts surrounding it, 0.952 ; length of the legs from the top $2 \cdot 16$; width at base $0 \cdot 86$, but this varies; length of claw-bearing joint $0 \cdot 26$; diameter of sexual opening with soft parts surrounding it 0.65 ; diameter of eye 0.11 ; diameter of papillæ from 0.04 to 008 ; length of claw $0 \cdot 15$; width of same at base $0 \cdot 105 . "$

"This specimen is in the possession of Professor Leuckart after whom I have named it by permission. A short diagnosis may be given as follows: fifteen pairs of legs; sexual organs between last pair; the "sole" consists of three segments, one long and curved, and two short and straight. New Holland, Australia."

By way of comment on the above it may be remarked:(1) Though neither the exact habitat, nor the name of the collector has yet transpired, "North-west from Sydney" is some- 
what less unsatisfactory than New Holland. I should take it to mean that the type specimen was found within the limits of New South Wales, somewhere between Sydney and Cassilis - at which place Mr. Olliff obtained the otherwise first recorded specimen from this colony - or thereabouts, but not much further to the west or north-west of the latter. It is hardly probable that over thirty years ago Peripatus was found in the then newly separated colony of Queensland at any spot in a direction N.W. from Sydney, say to the north of Bourke. Not only would such a locality then have been very much less easy of access to a zoological collector than it is now; but it would, I should think, be one with a climate altogether too dry for Peripatus. This being so, it is a curious fact-not however without a parallel,that so long ago somebody should have casually found somewhere in this colony a single specimen of Peripatus with 14 pairs of walking legs, but that similar specimens, whether from New South Wales or Queensland, notwithstanding much collecting, should still be desiderata. Sedgwick has probably had to do with more individual specimens of Peripatus than all other naturalists put together; and yet among the specimens- "more than a thousand from the Cape Peninsula"-which came under his notice, P. brevis, de Blainv., was conspicuously absent, and in the flesh was unknown to him at the time the Monograph was written. In the Macleay Museum is a specimen of a Peripatus with 15 pairs of walking legs, labelled Tasmania, to which Mr. Masters directed my attention in 1890 (P.L.S. N.S.W., 2nd Ser., Vol. v., p. 469). At that time Mr. Masters considered that it had been at least ten years in the collection, and he still thinks that the correctness of the reputed locality is not open to question. The label is in his own writing, but he is unable to recall the exact circumstances under which the specimen came to hand. Recently Prof. Baldwin Spencer was successful in finding Peripatus in Tasmania, but some fifteen specimens obtained had 14 pairs of claw-bearing legs apiece.

(2) It was not Prof. Leuckart's intention to furnish a technical description of his specimen. On the other hand Sänger's description was about as full as it could be expected to be under the 
circumstances; the situation of the genital aperture, the number of the spinous pads (soles), and the arrangement of the primary papillæ on the claw-bearing joints of the legs, all being duly noted. Moreover, he gives six figures of various parts of the specimen. His examination of it was therefore of a more or less minute character, and it is hardly possible that he should have incorrectly counted the number of the walking legs.

(3) The only reference to the description of $P$. brevis, de Blainville, [not Blanchard] given by Sclater and Sedgwick-besides de Blainville, "Dictionnaire des Sciences Naturelles," Supplement, T. i., p. 237, Paris, 1840, which I am unable to consult-is the footnote to Gervais' paper "Etudes pour servir à l'histoire naturelle des Myriapodes" in the Ann. Sc. Nat. (2), vii., p. 38, 1837. This, however, is but the abbreviated description, quoted by Sedgwick (Monograph, p. 168), which mentions "pourvu de quatorze paires de pattes," but does not disclose what view de Blainville took of the oral papillæ, nor exactly what the fourteen pairs were to be understood as comprehending. In Gervais' paper "Sur le Genre Peripate"* is incorporated a detailed description

* Ann. Françaises et Etrangères d'Anat. et de Physiol. T. ii. p. 309, 1838. Abstract in Revue Zoologique, par la Soc. Cuvierienne, Année, 1838, pp. 264-265.

In the same paper (pp. 314 and 310) Gervais says "celıi qu' a vu M. Macleay étrait de Cuba," having previously stated " et M. Macleay, qui en parle d' une manière transitoire dans un note publié depuis plusieurs années, dit aussi qu' ils ont des rapports avec les vers et en même temps avec les Myriapodes (Zoological Journal)." Sedgwick (l.c. p. 197) remarks, "Blanchard refers to a Peripatus found in Cuba by Mr. Macleay. He regards it as belonging to the species juliformis. I have been unable to find any account of this Cuban species."

The only reference to Peripatus by W. S. Macleay I can find in the Zoological Journal is contained in a postscript to a letter written from Havanna to Mr. Vigors (Vol. iv. p. 278). It takes exception to Guilding's view of Peripatus as a mollusc, suggests other affinities, and adds "There is a specimen in my father's collection " [at that time in Australia]. But it seems to me to offer no ground for associating the record of a Cuban species with W. S. Macleay's name. 
of $P$. brevis communicated by de Blainville, and given in his own words. From this it appears that the "quatorze paires de pattes" has reference only to claw-bearing legs. The oral papillæ he thus describes-"Quant aux appendices: la tête est pourvue d'une paire de tentacules simples. . . . On remarque à la partie externe de leur base, et par conséquent de chaque côté, un stemmate ou un point pseudo-oculaire formé par un petit disque cordé, un peu convexe et simple." Upon this Gervais remarks: "M. Wiegmann considère comme des pattes atrophiées les deux organes que MM. Guilding, de Blainville, Audouin et Edwards signalent comme des yeux."

(4) There is nothing remarkable about the colour of the specimen. I have seen specimens (with 15 pairs of legs), from Queensland and New South Wales, which might be described in very similar or identical terms.

(5) I do not understand the statement that "the claw-bearing joint which follows these segments [spinous pads], is distinguished by its 4-cornered appearance due to a pair of papillce at its outer corners, one on each side ( $P$. capensis has three)." The statement as to $P$. capensis is borne out by Sänger's figures; and both are in harmony with the quite independent observations and figures of Sedgwick, who says that there are two primary papillæ on the front or anterior side of the distal end of the foot, close to the socket in which the claws are placed, and one on the posterior side. In the Australian and New Zealand species the distal end of the foot also has three primary papillæ, but they are differently arranged, one being anterior, one posterior, and one median and dorsal. At least two of his figures (figs. 32, 33 and perhaps 34) show that Sänger correctly recognised this character in the Australian Peripatus. His fig. 35 is certainly very satisfactorily 4-cornered, three of the corners being furnished by the three papillæ in question, while the fourth is apparently an equally conspicuous similar primary papilla which is median and ventral; but with which the Australian Peripatus has not been credited by any other observer. Even so, the statement "a pair of papillæ at its outer corners, one on each side," hardly seems to express 
this arrangement very intelligibly. What I find is a pair of elevations at the distal end of the ventral aspect, one on each side of the median line, and each of them without about two spines; they are comparable with the similarly situated but more extensive groups of "inconspicuous pale elevations, bearing spines" in $P$. capensis referred to by Sedgwick ( $l$. c. p. 163). Sänger, too, noticed them in that species, but in his fig. 5 they are represented like a pair of primary papillæ, each bearing one spine.

Since then the type of $P$. leuckarti, Säng., has 14 pairs of walking legs, a question which naturally offers itself for consideration is-how ought the common, more widely distributed Australian Peripatus with 15 pairs of walking legs to be designated? Some months ago I had the opportunity of discussing the question with Dr. Dendy in the light of Prof. Spencer's translation. As the variation in the number of claw-bearing legs, as far as was then known, appeared to be correlated with a variation in the character of the outer jaw blades it seemed not unreasonable to regard the Peripatus with 15 pairs of walking legs as distinct from $P$. leuckarti, Säng., and entitled to a new name; Dr. Dendy even considering himself justified in regarding the larger Victorian Peripatus as sufficiently distinct from that of New South Wales to merit independent specific rank. And we intended to act accordingly.

Quite unexpectedly, only last week, I received from Mr. A. M. Lea, of West Australia, a small consignment of specimens from that colony, the examination of which, as it seems to me, throws important light on the question propounded above, and has compelled me to modify my views. Each of five specimens has 15 pairs of walking legs, and the jaw-blades removed from one of them are without an accessory tooth at the base of the fang of the outer blade. Under the old régime it would have seemed to be a moot point whether they should be called P. insignis, Dendy, var. with 15 pairs of legs, or $P$. leuckarti, Sänger, var. without an accessory tooth; indeed in the absence of males they might almost have been referred to $P$. nova-zealandia, Hutton. If the 
eastern form is to be regarded as a species distinct from what we must now consider to be $P$. leuckarti, Säng., then the western form also, as it seems to me, ought to be so regarded. I would prefer to consider the latter an intermediate form, as at present Australia would, I think, be over-supplied with as many as four. species. Seeing that many more specimens have had their legs counted, than have had the jaw blades examined, and that in two examples from New South Wales, in one or both outer blades there is more than one accessory tooth,-in one case three on the jaw blade of one side; in another the accessory tooth, longer and blunter than usual, is followed by several serrations; in both examples the peculiarities are reproduced in the reserve teeth-it seems probable that unlooked for variation. may be found. Further, Dr. Dendy has recently recognised as a var. of P. novce-zealandice a New Zealand Peripatus with 16 pairs of walking legs*; so that the idea that in this species the number of feet is "fixed," must now be given up. Therefore the most satisfactory arrangement, in my opinion, would be to consider all the known Australian specimens of Peripatus as referable to one comprehensive species with four varieties as follows:-

\section{Peripatus leuckarti, Säng.}

With 14 or with 15 pairs of claw-bearing ambulatory legs. Outer jaw-blades without or with an accessory tooth, occasionally more, at the base of the main tooth. Males smaller than the females; with a pair of (accessory gland) pores close together, situated between the genital papilla and the anus; with a white or sometimes bluish tubercle - on which opens the crural glandon each leg of the first pair only, or of the last pair only, or of all or only some of the pairs with the exception of the first, or of the first five.

Colour varying from dark blue or almost so, so dark sometimes as to appear blackish, with a still darker median dorsal line in the centre of which lies a fine unpigmented groove; to alternate

* Ann. Mag. N. H. (6) Vol. xiv., Dec. 1894, p. 401. 
longitudinal stripes of blue and orange or their equivalents - three of the former and four of the latter; or red with two of the dark stripes represented only by blackish blotches and discontinuous irregular patches. With an interesting series of more or less gradational colour-varieties arising from some modification of the following pattern: the dorsal surface is a mosaic of three longitudinal series of roughly hexagonal or lozenge-shaped areas outlined in dark upon a lighter background, bordered on each side by a light longitudinal stripe immediately above the insertion of the legs; the lozenges of the median series are confluent, the boundaries between them having disappeared, they correspond with the legs, and down the middle of the series dividing it symmetrically is a dark-blue, black, or rarely red-line often presenting as it were a knot-like enlargement in the middle of each lozenge, the dark line having down the centre of it a fine unpigmented sometimes interrupted groove. From the relative proportions of blue and orange or their equivalents present, from the partial or more or less complete disappearance of the dark reticulate pattern, or from the subdivision of the median series of lozenges into two sets of four-sided or diamond-shaped areas result some very interesting and, without a series for examination, sometimes very puzzling combinations. The legs sometimes appear as if inserted on a dark longitudinal stripe. The colour of the ventral surface is paler, but not less varied than that of the dorsal surface; generally speaking, it presents shades of the predominant tints of the dorsal surface. A discontinuous median series of small pale areas devoid of papillæ down the middle of it (ventral organs), one or sometimes two to each pair of legs.

As in $P$. novce-zealandice, the generative opening is between the legs of the last pair; the claw-bearing legs have three spinous pads; and a primary papilla projects from the median dorsal portion of the foot.

$H a b$. - In suitable situations in the table-land and coastal regions of Queensland and New South Wales, widely distributed but not abundant; Victoria; Tasmania; and West Australia. 
1. P. Leuckarti, Säng., var. typica

P. leuckarti, Säng., non auct.: P. insignis, Dendy, Vict. Nat. Vol. vi. No. 12, April, 1890, p. 173; Spencer, Proc. Roy. Soc. Vict. 1894, p. 31.

With 14 pairs of claw-bearing legs; outer jaw blades without an accessory tooth.

Hab.-New South Wales, Victoria, Tasmania.

The re-discovery of this variety in New South Wales is a matter to be desired, as the jaw characters of the type are unknown. I have seen only Tasmanian specimens-six (three of each sex) kindly lent me by Prof. Spencer. Two of them are dark without any definite pattern; the others hare more orange red and show a dark median line with nodosities, not always opposite the legs, and a pattern of secondary diamonds, much like some N.S.W. specimens of var. orientalis. The males are remarkable by the absence of white tubercles from the legs of the first five pairs; they are present on all or nearly all the others.

2. P. Leuckarti, Säng., var. occidentalis, var. nov.

With 15 pairs of walking legs; outer jaw-blades without an accessory tooth.

Hab.-Bridgetown, inland from Perth, W.A: (Mr. A. M. Lea).

The specimens, which were put straight into spirit, are small (the largest but slightly exceeding $15 \mathrm{~mm}$.) even allowing for the contraction due to the method of preservation. There is nothing specially remarkable about the coloration, which is mainly blue, with a smaller amount of orange. They would pass muster in this respect very well among a collection of similarly preserved eastern specimens.

The males have white papillæ on-most of the legs, but not on those of the first pair. One of the females obtained and preserved on March 30th last contained about ten advanced embryos varying slightly in age, of which the proximal one has the body more pigmented than is usually the case with the newly born young of the eastern form. As in the latter, the embryos are contained 
within a thin hyaline membranous shell. The breeding season, at any rate as to its termination, would seem to be in agreement in the two cases.

Several living examples forwarded at the same time, unfortunately in the same enclosure as the spirit specimens, miserably perished on the journey.

\section{P. Leuckarti, Säng., var. orientalis.}

P. leuckarti, Säng., of authors, but not of Sänger; nor the larger Victorian Peripatus of Dendy.

With 15 pairs of walking legs; outer jaw-blades with one accessory tooth or with several. Length of largest specimens extended after drowning - Q. $50 \mathrm{~mm}$; 命. $29 \mathrm{~mm}$. (the antennæ being excluded).

Hab.-[Queensland*]; New South Wales (not yet found west of the Dividing Range).

I now possess a fine series of specimens from this Colony, but it does not include a single specimen normally with 14 pairs of clawbearing legs. Of one specimen the legs of the fourteenth pair are without claws, while the fifteenth pair is represented by a pair of small white symmetrical stumps, between which, however, the generative aperture is placed: I should suppose that this specimen was recovering from some injury to the hinder end of the body. I have several times seen a specimen with one leg on one side missing.

My series presents a very remarkable variety of colour and pattern. The specimens might very well be sorted out into something like ten distinguishable, but more or less gradational, lots. If the whole of the median series - with the exception, of course, of the very dark median line-be filled in with red, the mosaic of lozenges then becomes very distinct, as in that case the

* My remarks must be understood as applying more particularly to the Peripatus of New South Wales, as I have had the opportunity of examining only a few Queensland specimens ( $\delta$ 's), and no observations on the breeding habits of the Queensland Peripatus are known to me. 
stripes above the legs will be almost entirely red, contrasting well with the intervening series. Interesting variations of this pattern arise by the partial filling in of the lozenges of the median series; the red may be aggregated in a little patch on each side of the nodose enlargement on the median dark line, or it may just fill in the lateral apices of each lozenge. The most complicated pattern arising from a secondary arrangement of (four-sided) diamonds may be described as follows: Two lines intersecting in each nodose enlargement of the median dark line cut off from a lozenge a pair of small diamonds, one on each side of the median line corresponding with the legs; and an anterior and posterior portion which, with the posterior portion of the lozenge preceding, and the anterior of the succeeding one, make up two of a single median interrupted series of larger diamonds, each of which corresponds with the interval between the legs* : the former are sometimes filled in with red; the latter partially. Sometimes the dark boundaries disappear, leaving only the patches of red. The light longitudinal stripe above the insertion of the legs is usually very distinct, but sometimes there are only indications of it, or it is a discontinuous series of orange or red patches above the intervals between the successive legs of each side. Its light tint may be due to the presence of light blue both in the ground colour, and on the primary papillæ with the exception of their summits.

I have seen only a very small series of the larger Victorian Peripatus, but as far as it goes the following slight differences attract my notice. The median dark longitudinal line is either wanting or is not so marked a feature as in our variety; and the unpigmented median groove is rather more conspicuous. The line of demarcation between the median and each lateral series of the mosaic is better defined; that between the lateral series and the longitudinal stripe is not, I think, quite so definite. The longitudinal stripe above the legs, except in specimens with a very large amount of red, is not so clearly indicated as is usually

* That is, the interval between two consecutive legs of the same side. 
the case in ours. These differences, however, are not more striking than those which may be presented by a number of individual specimens from New South Wales found in the same $\log$.

Such slight local variations, as well as in the secondary sexual characters of the males, are not uncommon. I have had a good deal of experience now with the Peripatus of New South Wales, but I never yet met with longitudinally striped examples such as Mr. Helms got at Mt. Kosciusco, and Mr. Lea on the northern Tableland. On the other hand, some of my own examples are unlike any I have seen among those collected by others in localities which I have not myself visited. From one district my specimens are characterised by a red tail. Illawarra specimens commonly have a well-marked nodose median dark line, each nodosity standing in a rather triangular patch of red, but with little or no indication of a lozenge pattern; and in these specimens the median ventral series of white patches (ventral organs) are very inconspicuous indeed. It was such specimens as these that first came under my notice; and the relation of their colourpattern to the diamond pattern of the Victorian Peripatus described by Dr. Dendy failed to suggest itself. I have now examples from other localities in New South Wales which show the chequer pattern as characteristically as Victorian examples.

The males usually have papillæ on all or most of the legs after the first pair, but among specimens from one district I find males with papillæ on the legs of the flrst pair only to predominate, though in two other examples there is also an additional papilla on one leg of the second pair. In the first case crural glands appear to be absent from the legs of the first pair; and of the remainder when papillæ are wanting on some of the legs crural pores may still be recognisable. In the second case crural glands seem to be present only in the legs of the first pair-rarely an additional one in one leg of the second pair. I have seen at least thirty males with papillæ on the legs of the first pair only. Two of these Mr. J. P. Hill, 
Demonstrator of Biology, Sydney University, very kindly sectionised for me. The legs did not all cut in an equally satisfactory manner; but allowing for this, beyond a large pair of crural glands in the two papilla-bearing legs, I can see no indication of their presence in the others. I have not seen any specimen with papillæ on the legs of the last pair only. When papillæ are present on the legs of the last pair they are situated nearer the base of the leg than in the case of the others. This, however, is because the legs of the fifteenth pair are shorter, and consequently have fewer transverse papilla-bearing ridges. The papillæ still occupy the normal portion - namely, on about the fifth papillabearing ridge above the innermost spinous pad.

In a previous paper (P.L.S.N.S.W. 2nd Ser. v. p. 484) I referred to the presence in some females of longitudinal slit-like depressions or pores situated a little below the nephridiopores, and suggestive of rudiments or relies of crural glands. They are not, however, the representatives of the crural glands of the males, for I now have specimens of the latter, both with numerous crural papillæ and with only one pair which show the same character. In the males they are situated between the nephridiopore and the papilla when present, or the position it would occupy if present. Occasionally, even in the females, a little white coagulated secretion is left in the aperture. Unless these represent a second series of crural glands which were possessed by both sexes, but are now becoming more or less aborted, I do not at present know what they can be.

The ova are large, and have a considerable amount of yolk. As in P. capensis, the egg-shell is a thin transparent membrane; not a thick chitinous covering as in $P$. novce-zealandice, and in the larger Victorian Peripatus.

There is some difference in detail in respect of the breeding habits of the New Zealand Peripatus and that of New South Wales as known to me; and in neither case is it so easy, as in that of $P$. capensis, to fix definitely the length of the period of gestation, or the exact limits of the breeding season; and, I should imagine, for a similar reason. 
Of $P$. capensis, Sedgwick says: "The period of gestation is thirteen months; that is to say, the ova pass into the oviducts about one month before the young of the preceding year are born. . . . . The young are born in April and May" (Monograph, p. 165).

Of $P$. novce-zealandice, Captain Hutton says that it appears to breed all the year round; and that he found the uterus crowded with embryos in September and November. The views of Mr. Sedgwick and Miss Sheldon are summed up by the latter as follows :- "Probably the ova pass from the ovary into the uterus in December, and the young are born in July, the development thus occupying a period of about eight months. This, though apparently usually the case, cannot be universal, since in each lot there were one or two females which contained embryos ready for birth, and also the embryos in one female vary somewhat in age."

Sclater, therefore, hardly satisfactorily states the case when he says of both the South African and the New Zealand Peripatus that "the development of the embryos, though going on all the year round, commences at one particular season, so that all the embryos found in the uterus of the female are approximately of one age." (Studies from the Morph. Lab. Cambridge, Vol. iv. p. $215,1889$.

Of the Neotropical species, Sedgwick remarks:- " Embryos of very different ages in same uterus, and births probably taking place all the year round"; and of P. Edwardsii- "The uterus contains embryos in all stages of development, and the young, which are fully developed at birth, are presumably born at different times of the year." (Monograph, pp. 184 and 190.)

The Australian Peripatus with which I am familiar seems in these matters to occupy an intermediate position between $P$. capensis and the Neotropical species. If one cannot say of it that it breeds all the year round, or that the uterus contains embryos in all stages of development, still less can one definitely particularise any single month as par excellence the breeding season; or assert that embryos of approximately one age only are to be found in pregnant specimens. And, so far as I can judge, 
I should think the New Zealand Peripatus is not widely different in this respect from ours.

I have examined females of the common Peripatus of New Wales at intervals during the greater part of the year. There are still a few important blanks in my series when certain details are wanted, which I hope soon to be able to fill. I shall, therefore, postpone a full consideration. But I have seen enough to show the general trend of matters.

Of the first lot of specimens I ever had, one specimen was kept from June 16th to the last week in October : a few days before her death she produced four young ones. In July an embryo which had about half completed its development was removed from another female of the same batch, and preserved by Professor Haswell. I still have this specimen.

In 1892 I had specimens under observation from April until the following March; the first young one was noted on November 11 th.

In $1893 \mathrm{I}$ got a fine series in the last week of July. A single unusually early young one was noticed on August 15th. A few others were noticed on September 22nd. By November the females were breeding freely, sixty young ones being noted on November 22nd. From 15th-18th of August seventeen females of this batch in process of being drowned extruded 83 young embryos (from 1-14 each): these vary slightly in age, and comprise specimens at about the same stage, and also at a little more advanced stage, than the New Zealand embryo figured by Miss Sheldon (Studies, Vol. iv. Pl. xxvi. figs. 25-26) ; that is to say, the longitudinal ridge along each side of the body from which the appendages take their origin, shows rudiments of from about half a dozen pairs to nearly the full number. During the following week three females were opened; they contained 23, 30 and 37 very similar stages, together with younger ones and a few ova. In the first week in October five females of the same lot when being drowned extruded eight embryos; these are much more advanced than those extruded six weeks earlier, the full number of claw-bearing legs being present. The following week two 
females were opened; each of these contained about 39 very similar old embryos, a few of the proximal ones having the tentacles noticeably pigmented.

Two lots obtained early in January at the same locality in different years began to produce young towards the end of the month, young being especially numerous during February.

On April 2nd, 1893, I obtained a small batch of specimens; within the next fortnight six young ones were observed.

I have seen newly-born young in every month from August (only one specimen) to the early part of May. I have never seen them during the latter part of May, or in June and July, and in August only one surprisingly early specimen; and I should be surprised to find our Peripatus breeding during the winter months. Thus, while it will be seen that according to my experience, one cannot say of our common New South Wales that it breeds all the year round, yet it certainly does during the greater part-about three-fourths-of the year. The majority of the young I should say were born during a period of six monthssay from October to March; but the progeny of a few early breeders and a few late breeders add another three months. But if it cannot be said to breed quite all the year round, still less can any particular month by itself be selected as the breeding season. And as to the contents of the uterus, I do not find in the same female embryos in all stages of derelopment, nor yet embryos which are all of the same age.

The earliest date at which I have happened to examine females containing ova which had recently passed into the uterus is about the middle of April; the latest about the middle of October. In both cases, as well as in a female opened in the first week in August, there were also enlarging ovarian ova in various stages. Further observations will, I have no doubt, slightly extend this period during which at intervals ova mature and pass into the oviducts. From about the middle of March, or in exceptionally early cases towards the 'end of February or beginning of March, to about the middle of November or 
exceptionally a little later, will very probably prove to be not very wide of the mark.

If the unusually early August young one referred to above was developed from an ovum which passed into the oviduct about the middle of February; the October young from April ova; and the young born towards the end of April or early in May from ova which left the ovaries in October or November preceding -as may very well have been the case - then the period of gestation is about six months; not less, probably a little more; but from 6-7 months will, I believe, prove to be a very close approximation to the truth.

The largest number of New Zealand Peripatus embryos met with by Captain Hutton was $26(18+8)$; by Mr. Sedgwick or Miss Sheldon $18(12+6)$. The largest number I have found in our Peripatus is 53, in a female opened on November 21st. They form a finely gradational series of old embryos - the youngest with claw-bearing legs, the proximal half dozen or so with pigmented tentacles. Females with from 30-40 embryos or ova are not uncommon in certain months. * Whether the contents of the uteri show any very marked differences in the stages of derelopment reached depends a good deal on circumstances. About the time when the breeding season usually ends one may find females containing a few old embryos not differing very noticeably, or nothing, or a few old embryos together with a few ova which have recently passed into the uteri, or only some of the latter. Still later in the season one may find an increased number of young embryos together with fresh ova. But my experience is that if the contained series is a large one, as a rule it presents no very abrupt breaks, but one gets a finely graduated series of old or of

* On the other hand, when the supply of material has been short, and small and therefore young specimens-possibly even commencing to breed for the first time--have had to be utilised, the numbers have been very small compared with what might be expected to occur in large examples opened at the same time of year. In two such cases the numbers were only two and one respectively. 
young stages varying slightly in age. Also that in different females one may find at different times of the year separated by an interval of as much as six months embryos at the same stage of development.

On several occasions I have found a few embryos which had been prematurely extruded by females living in captivity.

[4. The Victorian Peripatus to be dealt with by Dr. Dendy.

Hab.-Victoria and Tasmania (probably-for a specimen in the Macleay Museum)]. 


\section{$2 \mathrm{BHL}$ Biodiversity Heritage Library}

Fletcher, J. J. 1895. "On the specific identity of the Australian Peripatus usually supposed to be P. leuckarti, Sänger." Proceedings of the Linnean Society of New South Wales 10, 172-194. https://doi.org/10.5962/bhl.part.24340.

View This Item Online: https://www.biodiversitylibrary.org/item/30097

DOI: https://doi.org/10.5962/bhl.part.24340

Permalink: https://www.biodiversitylibrary.org/partpdf/24340

\section{Holding Institution}

MBLWHOI Library

\section{Sponsored by}

MBLWHOI Library

\section{Copyright \& Reuse}

Copyright Status: NOT_IN_COPYRIGHT

This document was created from content at the Biodiversity Heritage Library, the world's largest open access digital library for biodiversity literature and archives. Visit BHL at https://www.biodiversitylibrary.org. 